\title{
Correction to: Augmentation uretero-enterocystoplasty for refractory urinary tract dysfunction: a long-term retrospective study
}

Xiaogian Ying ${ }^{\dagger}$ and Limin Liao ${ }^{*+}$

\section{Correction to: BMC Urology (2021) 21:166} https://doi.org/10.1186/s12894-021-00927-z Following publication of the original article [1], the authors would like to correct the affiliation information for authors. It has been corrected in this correction.

1. Department of Urology, Beijing Boai Hospital, China Rehabilitation Research Centre; School of Rehabilitation of Capital Medical University; No10. Jiaomen Beilu, Fengtai District, Beijing 100068, China.

2. "Department of Urology of Capital Medical University, Beijing 100068, China", should be removed.

The original article [1] has been corrected.

\section{Publisher's Note}

Springer Nature remains neutral with regard to jurisdictional claims in published maps and institutional affiliations.

Published online: 16 February 2022

\section{Reference}

1. Ying $X$, Liao L. Augmentation uretero-enterocystoplasty for refractory

urinary tract dysfunction: a long-term retrospective study. BMC Urol. 2021;21:166. https://doi.org/10.1186/s12894-021-00927-z.

The original article can be found online at https://doi.org/10.1186/s12894021-00927-z.

*Correspondence: Imliao@263.net

${ }^{\dagger}$ Xiaoqian Ying and Limin Liao: co-first authors

Department of Urology, Beijing Boai Hospital, China Rehabilitation

Research Centre, School of Rehabilitation of Capital Medical University,

No10. Jiaomen Beilu, Fengtai District, Beijing 100068, China

(c) The Author(s) 2022. Open Access This article is licensed under a Creative Commons Attribution 4.0 International License, which permits use, sharing, adaptation, distribution and reproduction in any medium or format, as long as you give appropriate credit to the original author(s) and the source, provide a link to the Creative Commons licence, and indicate if changes were made. The images or other third party material in this article are included in the article's Creative Commons licence, unless indicated otherwise in a credit line to the material. If material is not included in the article's Creative Commons licence and your intended use is not permitted by statutory regulation or exceeds the permitted use, you will need to obtain permission directly from the copyright holder. To view a copy of this licence, visit http://creativecommons.org/licenses/by/4.0/. The Creative Commons Public Domain Dedication waiver (http://creativecommons.org/publicdomain/zero/1.0/) applies to the data made available in this article, unless otherwise stated in a credit line to the data. 